Reprod. Nutr. Dévelop., 1982, 22 (5), 785-792.

\title{
Influence of hypophysectomy and prolactin on the rat pinealocyte : a quantitative ultrastructural study
}

\author{
M. KARASEK $\left({ }^{*}\right)\left({ }^{* *}\right)$, A. LEWINSKI $\left({ }^{* *}\right), J . T . \operatorname{HANSEN}(*)$, R. J. REITER $\left({ }^{*}\right)$ \\ (*) Department of Anatomy, The University of Texas Health Science Center at San Antonio, \\ San Antonio, Texas, USA. \\ (**) Laboratory of Electron Microscopy, Department of Pathological Anatomy, Institute of \\ Pathology, Medical Academy, Lodz, Poland. \\ (**) Department of Experimental Endocrinology, Institute of Endocrinologv, Medical Academy, Lodz, \\ Poland.
}

Summary. The effects of hypophysectomy and prolactin administration on the ultrastructure of rat pinealocytes were studied by means of morphometric analysis. Hypophysectomy resulted in an increase in the Golgi apparatus and dense-core vesicles and a decrease in the granular endoplasmic reticulum, lysosomes and lipid droplets. Prolactin administration induced an increase in the granular endoplasmic reticulum and in the vacuoles which contained a flocculent material. Administration of prolactin to hypophysectomized rats raised the lowered levels of granular endoplasmic reticulum and lipid droplets to control values and caused an increase in vacuoles containing a flocculent material. Although hypophysectomy appeared to diminish the general activity of pinealocytes, it stimulated the neurosecretory-like secretory process (Golgi apparatus - densecore vesicles), whereas prolactin appeared to stimulate the ependymal-like secretory process (granular endoplasmic reticulum - vacuoles containing a flocculent material).

\section{Introduction.}

The influence of the pineal gland on reproductive functions has been clearly and convincingly demonstrated (for review and references, see Reiter, 1978, 1980). The pineal gland may exert its influence at all levels of the neuroendocrinereproductive axis (Reiter et al., 1981). Although the mechanisms by which the pineal gland influences the activity of the hypothalamo-hypophyseal-gonadal system are not fully understood, both pinealectomy and the presumptive pineal hormone, melatonin, can influence the release of adenohypophyseal hormones under a variety of experimental conditions (for review see, Johnson and Reiter, 1978 ; Reiter, 1980).

Address reprint requests to: Dr. M. Karasek, Department of Anatomy, The University of Texas Health Science Center at San Antonio, 7703 Floyd Curl Drive, San Antonio, Texas 78284, U.S.A. 
The ability of the pineal gland to affect prolactin (PRL) synthesis and/or release is a well-documented phenomenon (Johnson and Reiter, 1978). The involvement of the pineal gland in the regulation of PRL secretion is strongly suggested by the presence of prolactin-regulating substances in extracts of pineal glands (Blask et al., 1976 ; Chang et al., 1979). Prolactin, on the other hand, appears to be involved in the pituitary control of male reproductive functions in a variety of mammalian species (Bartke, 1980). A number of studies suggest that the effect of the pineal gland on gonadal activities may be mediated by PRL (Chang et al., 1979).

It has been demonstrated that pituitary hormones influence pineal biochemistry and morphology (see Cardinali, 1981 ; Karasek, 1981 ; Vollrath, 1981). However, qualitative ultrastructural studies of the pineal gland after hypophysectomy have produced contradictory results (Lupulescu, 1968 ; Satodate et al., 1970 ; Karasek, 1971). To the best of our knowledge, no investigations have been performed on the influence of PRL on the ultrastructure of the pineal gland. Therefore, we decided to perform a quantitative ultrastructural study of rat pinealocyte after hypophysectomy and PRL administration.

\section{Materials and methods.}

Sixteen male Sprague-Dawley rats, weighing 190-210 g were used in this study. The animals were kept in $12 \mathrm{~h}$ light : $12 \mathrm{~h}$ dark (lights on at $0600 \mathrm{~h}$ ). The animals were divided into 4 groups of 4 rats each. At the age of 50 days, hypophysectomy (HYPX) was performed on groups 1 and 2, whereas rats of groups 3 (control) and 4 were sham-operated (SH-HYPx). Hypophysectomy was performed by a transauricular approach with a device designed and constructed by Lewinski (1981). All rats used in this study were checked at autopsy at the termination of the experiment to assure that each animal had a complete hypophysectomy. On the eleventh day after surgery, rats of groups 1 (HYPX $+\mathrm{SAL}$ ) and 3 (SH-HYPX + SAL) received s.c. injections of $0.5 \mathrm{ml} 0.9 \% \mathrm{NaCl}$ (SAL) at $2200 \mathrm{~h}$, followed by a second injection on the next day at $0800 \mathrm{~h}$. The rats of groups 2 (HYPX $+P R L$ ) and 4 (SH-HYPx $+P R L)$ received $500 \mu \mathrm{g}$ of sheep prolactin s.c. (Luteotropic Hormone, Sigma : $30 \mathrm{IU}$ per $\mathrm{mg}$, purity greater than $99 \%)$ at the same time points. Three hours after the second injection, the animals were sacrificed by decapitation. Immediately following decapitation the pineal gland was removed, cut into 4 pieces and immersion-fixed in $5 \%$ glutaraldehyde in $0.1 \mathrm{M}$ cacodylate buffer. After $2 \mathrm{~h}$ of fixation, the tissues were washed overnight in $0.1 \mathrm{M}$ cacodylate buffer, postfixed in $1 \%$ osmium tetroxide, dehydrated in a graded series of ethanol solutions and embedded in Epon. Three blocks from each animal were selected at random for sectioning. Thin sections exhibiting light gold interference colors $(70-80 \mathrm{~nm})$ were stained with uranyl acetate and lead citrate and examined with a Siemens $1 \mathrm{~A}$ electron microscope. Ten micrographs, at a magnification of $\times 9,500$ were taken from each block, using systematic random sampling (Weibel, 1979). The upper lefthand corner of each grid aperture possessing pinealocytes was photographed 
until the appropriate sample set was obtained. The electron microscope was calibrated with a ruled diffraction grating (Ernest F. Fullam, Inc.). A total of 480 prints, enlarged to $\times 30,000$, was used for the quantitative study. A Zeiss MOP-3 image digital analyzer was used to obtain the morphometric data. The data are presented as the area (in $\mu \mathrm{m}^{2}$ ) of the different cellular components per $500 \mu \mathrm{m}^{2}$ of cytoplasm per animal \pm SEM. The following cytoplasmic organelles of the pinealocytes were analyzed: Golgi profiles (GP), dense-core vesicles (DCV), granular endoplasmic reticulum (GER), vacuoles containging a flocculent material (VFC), lysosomes (LYS) and lipid droplets (LD) (Karasek, 1981; Karasek et al., 1982). Significant differences among means of data collected from the four groups were determined by a one-way analysis of variance. Significant differences between any two groups were determined using a Newman-Keuls test.

\section{Results.}

Administration of $P R L$ to sham-operated rats resulted in a significant increase in the areas of GER, VFC and LD (table 1). In many cells, varge complexes of parallel-oriented cisternae of GER were observed (fig. 1). Following HYPx, a significant increase in the areas of GP and DCV was noted (table 1). In contrast, the areas of GER, LYS and LD were significantly reduced (table 1). Administration of PRL to hypophysectomized rats resulted in an increase in the areas of GER and LD to control values (table 1). The area of VFC also was significantly higher for this group as compared to SH-HYPX + SAL and HYPX + SAL. Although the area of GP was smaller in the HYPX + PRL group than that found in the HYPx + SAL group, it was significantly larger than that found in the SH-HYPX + SAL and SH-HYPX + PRL groups.

\section{Discussion.}

Numerical changes in the GP, DCV, GER, VFC, LYS and LD have been demonstrated in rats pinealocytes in varying natural and experimental conditions

TABLE 1

Areas of the Golgi profiles (GP), dense-core vesicles (DCV), granular endoplasmic reticulum (GER), vacuoles containing a flocculent material (VFC), lysosomes (LYS), and lipid droplets (LD) in the pinealocytes of sham-operated (SH-HYPx) and hypophysectomized (HYPX) rats treated with saline (SAL) or prolactin (PRL).

\begin{tabular}{lcccccc} 
& GP & DCV & GER & VFC & LYS & LD \\
\hline A. SH-HYP + SAL & $4.6 \pm 0.2^{\mathrm{a}}$ & $0.07 \pm 0.01^{\mathrm{c}}$ & $16.6 \pm 0.3^{\mathrm{d}}$ & $1.4 \pm 0.3$ & $3.3 \pm 0.5$ & $15.5 \pm 1.2$ \\
B. SH-HYPX + PRL & $5.0 \pm 0.4^{\mathrm{a}}$ & $0.06 \pm 0.01^{\mathrm{c}}$ & $26.7 \pm 2.0^{\mathrm{e}}$ & $3.0 \pm 0.2^{\mathrm{f}, \mathrm{g}}$ & $3.0 \pm 0.4$ & $21.3 \pm 2.0^{k, 1}$ \\
C. HYPX + SAL & $16.6 \pm 1.5^{\mathrm{b}}$ & $0.14 \pm 0.03$ & $9.1 \pm 0.7$ & $1.0 \pm 0.1$ & $1.7 \pm 0.2^{\mathrm{j}}$ & $7.5 \pm 0.9^{\mathrm{m}}$ \\
D. HYPX + PRL & $12.2 \pm 1.3$ & $0.12 \pm 0.01$ & $23.5 \pm 1.4^{\mathrm{e}}$ & $2.2 \pm 0.3^{\mathrm{h}, i}$ & $2.4 \pm 0.2$ & $15.9 \pm 1.9$ \\
\hline
\end{tabular}

Data are means \pm SEM per $500 \mu \mathrm{m}^{2}$ of pinealocyte cytoplasm per animal. a, $\mathrm{P}<0.01$ vs C, D ; b, $P<0.01$ vs $D ; c, P<0.05$ vs $C, D ; d, P<0.01$ vs $B, C, D ;$ e $P<0.01$ vs $C$; f, $P<0.01$ vs $A, C ;{ }^{g}, P<0.05$ vs $D ; h, P<0.05$ vs $C ;{ }^{i}, P<0.05$ vs $A ;$; ${ }^{\prime}, P<0.05$ vs $A, B$; k, $P<0.05$ vs $A, D ;$, $P<0.01$ vs $C ; m, P<0.01$ vs $A, D$. 


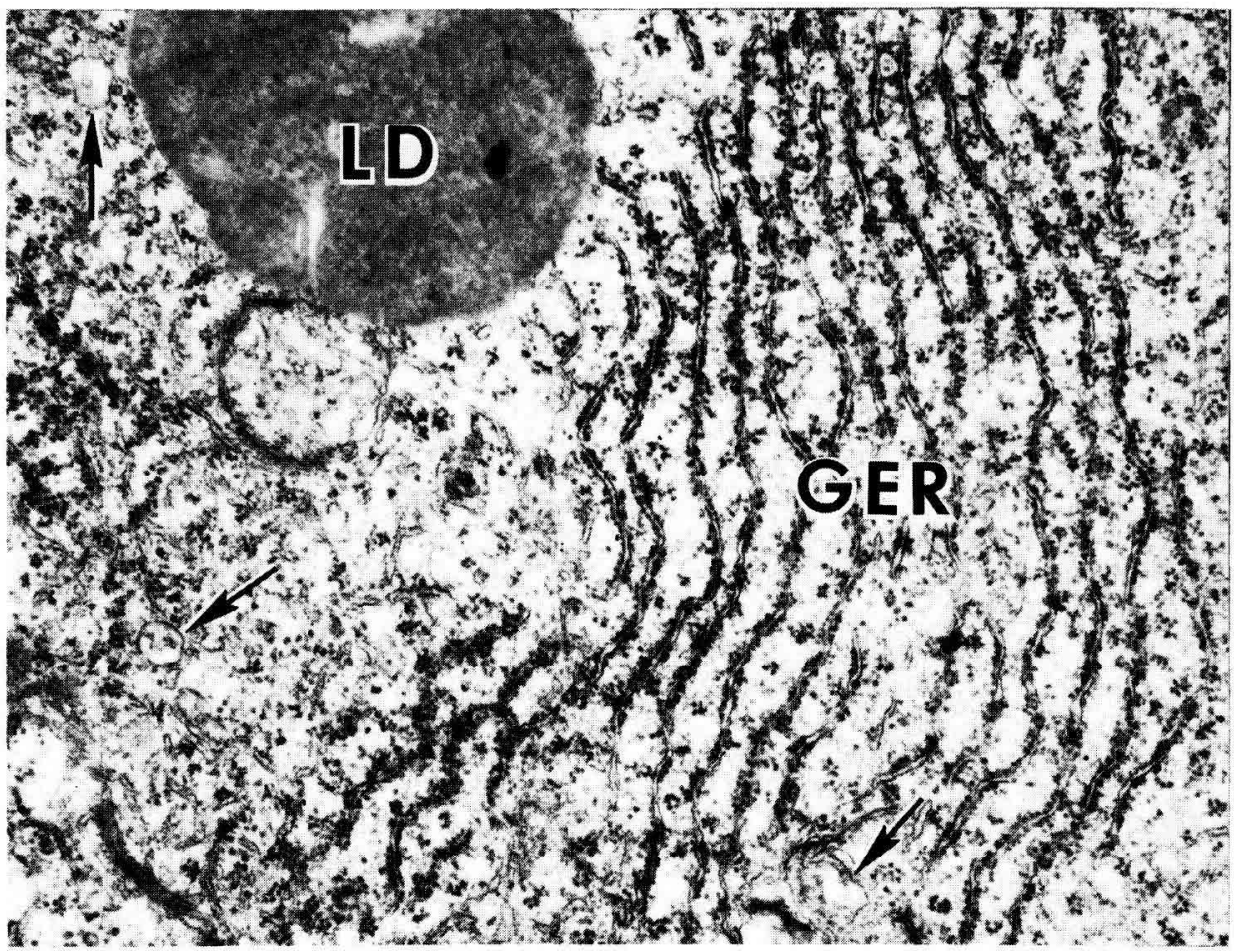

FIG. 1. - A large complex of the parallel-oriented cisternae of the granular endoplasmic reticulum (GER) in a sham-operated rat after prolactin administration. LD-lipid droplet; arrows point to vacuoles containing a flocculent material. $\times 27000$.

(Karasek, 1981 ; Karasek et al., 1982). The Golgi apparatus, DCV, GER and VFC are believed to be involved in the secretory processes of the pinealocytes (Pevet, 1979 ; Karasek, 1981), whereas the LYS and LD probably are involved in general cell metabolism (Quay, 1974), although a role of LYS in secretory processes in the pinealocytes also has been suggested (Karasek et al., 1976 ; Karasek, 1981).

The results of the present study, together with the known influence of the pineal gland on the hypophysis, support the existence of a reciprocal hypophysialpineal relationship. Both PRL and HYPx influence the ultrastructure of the pinealocytes. Moreover, administration of $\mathrm{PRL}$ to hypophysectomized rats reverses some of the effects of HYPX. It should be noted that PRL increases both pineal tyrosine hydroxylase activity (Cardinali, 1981) and hydroxyindole-O-methyl transferase activity (Cardinali and Vacas, 1978). High affinity binding sites for PRL detected in the pineal gland (Calvo, Charreau and Cardinali, unpublished data, cit. according to Cardinali, 1981) strongly support the existence of PRL receptors in the pineal gland. Of all the hormones influenced by the pineal gland, PRL often exhibits the most marked changes in level when the gland is manipulated (Reiter, 1980). In the rat, pinealectomy resulted in an increase in pitutiary levels of $P R L$ (Relkin, 1972) and a decrease in plasma PRL concentration (Relkin, 1972; Ronnekleiv and McCann, 1975). On the other hand, the putative pineal hormone, 
melatonin, depresses pituitary PRL stores (Reiter et al., 1976) and elevates plasma PRL levels (Kamberi et al., 1971 ; Vaughan et al., 1978). Arginine vasotocin, the putative pineal nonapeptide, also influences PRL secretion under a variety of experimental conditions (Vaughan and Blask, 1978). Pinealectomy (Donofrio and Reiter, 1972 ; Relkin et al., 1972 ; Blask and Reiter, 1975) or sympathetic denervation of the pineal gland (Blask et al., 1977) prevents changes in PRL levels which occur after light deprivation.

Although the decrease in GER, LYS and LD after HYPx points to a diminished activity of pinealocytes, the simultaneous increase in GP and DCV deserves attention. The decrease in GER, LYS and LD observed in the present study is in agreement with previous qualitative reports concerning ultrastructural changes in pinealocytes after HYPx (Lupulescu, 1968 ; Satodate et al., 1970 ; Karasek, 1971). A decrease in pineal lipid content after HYPx also has been demonstrated in the quantitative light microscopic studies by Zweens (1965). Since administration of pregnant mare's serum gonadotropin and human chorionic gonadotropin to hypophysectomized rats raises the lowered pineal lipid content to normal or above normal levels, Zweens (1965) suggests that this phenomenon is due to $\mathrm{LH}$. Gonadotropins activate the pinealocytes of the rat both in vivo and in vitro (Karasek and Marek, 1978; Karasek et al., 1978). However, since PRL also raises the lipid content in hypophysectomized rats to normal levels, the increase in LD after administration of PRL or gonadotropins to hypophysectomized rats may be due to an enhancement in general cell metabolism. The present observation of an increase in the Golgi apparatus after HYPX confirms earlier qualitative results of Karasek (1971), but not those of Lupulescu (1968).

The possibility that some effects of PRL might have been caused by possible contaminants of the PRL preparation used in the present study have been considered. However, purity of PRL stated to be greater than $99 \%$, and therefore we believe that changes in the ultrastructure of the pinealocytes are due to PRL.

It is noteworthy that HYPx reduces $\mathrm{N}$-acetyltransferase activity and melatonin production in the rat pineal gland by roughly $50 \%$ (Reiter et al., 1982). In the human, in 4 cases of panhypopituitarism, plasma levels of melatonin remained below the detectable limits of the radioimmunoassay at all times throughout a $24 \mathrm{~h}$ period (Wetterberg, 1978). Moreover, morphological signs of diminished activity of the pinealocytes have been observed in the dwarf mouse having hereditary hypopituitarism ; pituitary grafts, which are known to produce an increase in PRL and FSH levels, induce activation of these cells (Karasek, Bartke, King, Hansen and Reiter, unpublished results).

At least two types of secretory processes are reported to be present in mammalian pinealocytes (Pevet, 1977; Pevet and Karasek, 1977). The first process (neurosecretory-like) is characterized by the formation of DCV by the Golgi apparatus, while the second process (ependymal-like) is characterized by a peculiar activity in the granular endoplasmic reticulum. In rat pinealocytes, this activity is characterized by the formation of VFC by the cisternae of the GER (Karasek et al., 1976; Pevet and Karasek, 1977; Karasek and Marek, 1978 ; Karasek, 1981). Although the exact chemical nature of the substances present in 
DCV and VFC is unknown, both processes appear to be involved in the production of a proteinaceous material (Pevet, 1979). It is, however, possible that some secretory products of the pineal gland are not represented either by DCV or by VFC. Existence of another type of secretory process that cannot be visualized in electron micrographs of the pinealocytes should not be excluded. Compounds such as melotonin may merely be free in the cytoplasm and released from the cells by an as-yet-unknown process that is not apparent in electron microscopic images.

Hypophysectomy appears to stimulate the neurosecretory-like secretory process, whereas PRL appears to stimulate the ependymal-like secretory process. Inverse changes in both secretory processes also have been found in the pinealocytes of the rat during the last days of pregnancy (Karasek et al., 1982). This strongly suggests that both processes are involved in different regulatory mechanisms in the pinealocytes. Although this problem is still far from clear, we suggest that the ependymal-like secretory process is related to the regulation of PRL synthesis and/or secretion, whereas the neurosecretory-like process is involved in the regulation of some other adenohypophyseal hormones $(e . g$. gonadotropins).

Reçu en décembre 1981. Accepté en avril 1982.

Acknowledgements. - The authors wish to thank Dr. Andrzej Bartke for critically reading the manuscript and Ms. Nora Dimas for typing the manuscript. This investigation was supported by a grant from the Polish Academy of Sciences, within project 10.4 and by NSF grant no. PCM 8003441. Dr. Hansen is the recipient of a NIH Research Career Development Award \# K04 HL-00680.

Résumé. Les effets de l'hypophysectomie et de l'administration de prolactine sur l'ultrastructure des pinéalocytes ont été étudiés par analyse morphométrique chez le rat. L'hypophysectomie provoque un accroissement de l'appareil de Golgi et des vésicules à noyau dense et une diminution du reticulum endoplasmique granulaire, des lysosomes et des gouttelettes lipidiques. L'administration de prolactine s'accompagne du développement du reticulum endoplasmique et des vacuoles qui contiennent du matériel floconneux. Lorsque la prolactine est administrée à des rats hypophysectomisés, l'importance du reticulum endoplasmique granulaire et des gouttelettes lipidiques atteint le niveau observé chez les témoins; le nombre des vacuoles contenant du matériel floconneux augmente également. Bien que l'hypophysectomie semble diminuer l'activité globale des pinéalocytes, elle stimule les processus de type neurosécrétoire (appareil de Golgi, vésicules à noyau dense), tandis que la prolactine semble stimuler les processus sécrétoires qui se traduisent par le développement du reticulum endoplasmique granulaire et des vacuoles renfermant du matériel floconneux. 


\section{References}

BARTKE A., 1980. Role of prolactin in reproducion in male mammals. Fed. Proc., 38, 2577-2581.

BLASK D. E., REITER R. J., 1975. Pituitary and plasma LH and prolactin levels in female rats rendered blind and anosmic. Influence of the pineal gland. Biol. Reprod., 12, 329-334.

BLASK D. E., REITER R. J., JOHNSON L. Y., 1977. Pineal-induced alterations in reproductive function and pituitary prolactin in the female rat : the effects of bilateral superior cervical ganglionectomy and nervi corarii transsection. J. neurosci. Res., 3, 127-133.

BLASK D. E., VAUGHAN M. K., REITER R. J., JOHNSON L. Y., VAUGHAN G. M., 1976. Prolactin-releasing and release-inhibiting factor activities in the bovine, rat and human pineal. Endocrinology, 99, 152-161.

CARDINALI D. P., 1981. Hormone effects on the pineal gland, 243-272. In REITER R. J. The pineal gland, Vol. I. Anatomy and biochemistry. CRC Press, Boca Raton.

CARDINALI D. P., VACAS M. I., 1978 . Feedback control of pineal function by reproductive hormones. A neuroendocrine pradigm. J. neural Transm., Suppl. 13, 175-201.

CHANG N., EBELS I., BENSON B., 1979. Preliminary characterization of bovine pineal prolactin releasing (PPRF) and release-inhibiting factor (PPIF) activity. J. neural Transm., 46, 139-151.

DONOFRIO R. J., REITER R. J., 1972. Depressed pituitary prolactin levels in blinded anosmic female rats : role of the pineal gland. J. Reprod. Fertil, 31, 159-162.

JOHNSON L. Y., REITER R. J., 1978. The pineal gland and its effect on mammalian reproduction. Progr. Reprod. Biol., 4, 116-156.

KAMBERI I., MICAL R. S., PORTER J. C., 1971. Effects of melatonin and serotonin on the release of FSH and prolactin. Endocrinology, 88, 1288-1293.

KARASEK M., 1971. Ultrastructure of the epiphysis in white rats under normal conditions and after hypophysectomy. Pol. Endocr., 22, 13-26.

KARASEK M., 1981. Some functional aspects of the ultrastructure of rat pinealocytes. Endocr. Exp., 15, 17-34.

KARASEK M., MAREK K., 1978. Influence of gonadotropic hormones on the ultrastructure of rat pinealocytes. Cell Tiss. Res., 188, 133-141.

KARASEK M., LEWINSKA I., LEWINSKI A., HANSEN J. T., REITER R. J., 1982 . Ultrastructure of rat pinealocytes during the last phase of pregnancy. Cytobios (in press).

KARASEK M., MAREK K., KUNERT-RADEK J., 1978. Ultrastructure of rat pinealocytes in vitro : influence of gonadotropic hormones and LH-RH. Cell Tiss. Res., 195, 547-556.

KARASEK M., PAWLIKOWSKI M., KAPPERS J., ARIËNS, STEPIEN H., 1976 . Influence of castration followed by administration of LH-RH on the ultrastructure of rat pinealocytes. Cell Tiss. Res., 167, 325-339.

LEWINSKI A., 1981. Device for hypophysectomy in rats (in Polish). Biul. Urzedu Pat. PRL, 187, 106-107.

LUPULESCU A., 1968. Ultrastructure of the pineal gland after hypophysectomy. Experientia (Basel), $24,482-484$.

PEVET P., 1977. On the presence of different population of pinealocytes in the mammalian pineal gland. J. neural Transm., 40, 289-304.

PEVET P., 1979. Secretory processes in the mammalian pinealocyte under natural and experimental condition. Prog. Brain Res., 52, 149-194.

PEVET P., KARASEK M., 1977. Are the pineal active compounds of mammals proteinaceous in nature ? An ultrastructural contribution. Acta med. pol., 18, 351-353.

QUAY W. B., 1974. Pineal chemistry. Ch. C. Thomas. Springfield, III.

RELKIN R., 1972. Rat pituitary and plasma prolactin levels after pinealectomy. J. Endocr., 53, 179-180.

RELKIN R., ADACHI M., KAHAN S. A., 1972. Effects of pinealectomy and constant light and darkness on prolactin levels in pituitary and plasma and on pitutiary ultrastructure of the rat. J. Endocr., 54, 263-268.

REITER R. J., 1978. Pineal-mediated reproductive events, 369-370. In SPILMAN C. H., WILKS J. W., Novel aspects of reproductive physiology. Spectrum Publ. Co., New York.

REITER R. J., 1980. The pineal and its hormones in the control of reproduction in mammals. Endocr. Rev., 1, 109-131. 
REITER R. J., BLASK D. E., JOHNSON L. Y., RUDDEN P. K., VAUGHAN M. K., WARING P. J., 1976. Melatonin inhibition of reproduction in the male hamster: its dependency on time of day of administration and on an intact sympathetically innervated pineal gland. Neuroendocrinologv, 22, 107-116.

REITER R. J., RICHARDSON B. A., VAUGHAN M. K., JOHNSON L. Y., 1981. Pineal action and mechanisms in reproductive physiology. Jikeikai Med. J., 28, (Suppl. 1), 35-46.

REITER R. J., TRAKULRUNGSI W. K., TRAKULRUNGSI C., VRIEND J., MORGAN W. M., VAUGHAN M. K., JOHNSON L. Y., RICHARDSON B. A., 1982. Pineal melatonin production : Endocrine and age effects. In KLEIN D. C., Developmental neurobiology of the melatonin rhythm generating system, Karger, Basel (in press).

RONNEKLEIV O. K., MCCANN S. M., 1975. Effects of pinealectomy, anosmia and blinding on serum and pituitary prolactin in intact and castrated male rats. Neuroendocrinology, 17, 340353.

SATODATE R., SASAKI K., OTA M., 1970. The pineal gland of intact, hypophysectomized or ovariectomized rats. Light and electron microscopic studies. Arch. Neurol., 23, 278-286.

VAUGHAN M. K., BLASK D. E., 1978. Arginine vasotocin - a search for its function in mammals. Prog. Reprod. Biol., 4, 90-115.

VAUGHAN M. K., LITTLE J. C., JOHNSON L. Y., BLASK D. E., VAUGHAN G. M., REITER R. J., 1978. Effects of melatonin and natural and synthethic analogues of arginine vasotocin on plasma prolactin levels in adult male rats. Horm. Res., 9, 236-246.

VOLLRATH L., 1981. The pineal gland. Springer-Verlag, Berlin.

WETTERBERG L., 1978. Melatonin in humans: Physiological and clinical studies. J. neural. Transm., Suppl. 13, 289-310.

WEIBEL E. R., 1979. Stereological methods. Vol. 1. Acad. Press, London.

ZWEENS J., 1965. Alteration of the pineal lipid content in the rat under hormonal influences. Progr. Brain Res., 10, 540-551. 